\title{
Assessment of external and internal doses due to farming in high background radiation areas in old tin mining localities in Jos-plateau, Nigeria
}

\author{
N.N. JIBIRI ${ }^{1}$, S.K. ALAUSA ${ }^{2}$, I.P. FARAI ${ }^{1}$
}

(Manuscript received 8 July 2008, accepted 5 January 2009)

ABSTRACT Farming on soils situated in high background radiation areas can result to enhanced radiation exposure scenarios and pathways to humans. To assess the likely levels of exposures, farm soil samples were collected from different farmlands in three old tin mining localities (Bitsichi, Bukuru and Ropp) in Jos Plateau Nigeria, known for high radiations. The soil samples were analyzed for the activity concentrations of ${ }^{226} \mathrm{Ra}$, ${ }^{232} \mathrm{Th}$ and ${ }^{40} \mathrm{~K}$, using gamma-ray spectroscopy. The outdoor annual effective dose rates were calculated using the activity concentrations of the radionuclides and were found to vary from $0.07 \mathrm{mSv}$ to $2.02 \mathrm{mSv}$ across the three localities. Considering dust generation from soil tillage and inadvertent ingestion of soil particles, the likely internal radiation hazards were estimated using conservative dust and soil loading factors. The total average annual effective dose rates due to ${ }^{226} \mathrm{Ra}$ and ${ }^{232} \mathrm{Th}$ that could result from dust inhalation and ingestion of soil particles were $16.9 \mu \mathrm{Sv}$, $8.1 \mu \mathrm{Sv}$ and $8.8 \mu \mathrm{Sv}$, respectively for Bitsichi, Bukuru and Ropp. Though these values are about $5 \%$ of the outdoor exposures to the farmers in those farms and greater than $1 \mu \mathrm{Sv} \mathrm{y}^{-1}$, from the point of view of radiation protection and risk, they are significant. It suffices to say, therefore, that the results of this study will create the possibility of the importance to evaluate the health risk among the farming population and workplace environments which often is not covered by regulations concerning health protection.

Keywords: external dose / ingestion dose / inhalation dose / farming / natural radionuclides / farm soil / tin mining / activity concentration / Jos Plateau / Nigeria

RÉSUMÉ Évaluation des doses externes et internes dues à la culture sur des aires présentant un bruit de fond radiatif élevé, dans des localités du plateau Jos, Nigéria, où existent d'anciennes mines d'étain.

La culture de sols situés dans des zones où le bruit de fond radiatif est élevé peut avoir pour résultat des scénarios d'augmentation de l'exposition aux rayonnements, et de cheminement jusqu'à l'homme. Pour évaluer les niveaux probables d'exposition, nous avons prélevé des échantillons de sol cultivé provenant de diverses exploitations agricoles situées dans trois localités possédant d'anciennes mines d'étain (Bitsichi, Bukuru et Ropp), sur le plateau Jos (Nigéria), connu pour son rayonnement élevé. Par spectroscopie gamma des échantillons de sol, nous avons analysé les concentrations des activités de ${ }^{226} \mathrm{Ra},{ }^{232} \mathrm{Th}$ et ${ }^{40} \mathrm{~K}$. Nous avons calculé les débits de dose efficace annuels à partir des concentrations de l'activité des

Radiation and Health Physics Research Laboratory, Department of Physics, University of Ibadan, Ibadan, Nigeria.

Department of Physics, Olabisi Onabanjo University, Ago-Iwoye, Nigeria. 


\begin{abstract}
radionucléides ; nous avons trouvé qu'ils varient de $0,07 \mathrm{mSv}$ à $2,02 \mathrm{mSv}$, dans l'ensemble des trois localités. Tenant compte de la production de poussière dans le labourage du sol et de l'ingestion, par inadvertance, de particules venant du sol, nous avons évalué le risque probable venant du rayonnement interne, en utilisant des valeurs prudentes des facteurs de charge de la poussière et du sol. Les valeurs moyennes des débits de dose efficace annuels, dus à ${ }^{226} \mathrm{Ra}$ et ${ }^{232} \mathrm{Th}$, pouvant venir de l'inhalation et l'ingestion de particules du sol, étaient de $16,9 \mu \mathrm{Sv}, 8,1 \mu \mathrm{Sv}$ et $8,8 \mu \mathrm{Sv}$, respectivement, pour Bitsichi, Bukuru et Ropp. Ces valeurs représentent environ $5 \%$ des expositions, à l'extérieur des bâtiments, des agriculteurs de ces propriétés ; elles sont supérieures à $1 \mu \mathrm{Sv} \mathbf{a n}^{-1}$, donc significatives du point de vue de la radioprotection et du risque. Ainsi, il suffit de dire que les résultats de cette étude démontrent la possible importance d'évaluer le risque sanitaire que courent les populations des exploitations agricoles et de leur environnement, risque qui, souvent, n'est pas inclus dans les prescriptions de la radioprotection.
\end{abstract}

\title{
1. Introduction
}

Soils are the relatively thin film of heterogeneous particulate and fibrous matter which constitutes much of the land-atmosphere interface. They are a complex mixture of minerals, carbonaceous matter and water, in which live the vast range of soil micro- and macro-flora and fauna. Certain features are especially relevant to the problems of radioactively contaminated soils, especially the great variability of the soil-based (as distinct from aquatic-based) ecosystem in terms of chemical composition and of physical structure, and of environmental and exposure factors. Location, especially in relation to potential hazards such as mining zones, nuclear accident sites and radioactive fallout areas, is perhaps, the critical variable. Clearly, such variability will influence decisively the levels, behaviour and significance of radioactive contaminants reaching a particular soil-based ecosystem.

Farming activities or operations will create radiation exposure scenarios and pathways to humans in environments contaminated with radioactive elements. The magnitude of exposure apparently will be high in instances where high background radiation exist or during artificial fallouts and depositions. The land preparation source of the airborne soil particulate emissions are produced during the preparation of agricultural lands for planting and after harvest activities. Operations included in this methodology are ploughing, harrowing, leveling, ridges and furrows, earthing up, etc. Dust emissions are produced by the mechanical disturbance of the soil by the implement used. Emission load is equally split throughout the year assuming that agricultural operations occur throughout the year in the absence of a crop calendar which is very peculiar to peasant framers in Nigeria. These farming activities will result in the production of soil-dust particles and through inhalation and ingestion; radionuclides could be deposited in critical organs of the human body. Figure 1 shows the flow diagram of possible exposure scenarios and radiation pathways to humans at 3 different stages of farming activities. 


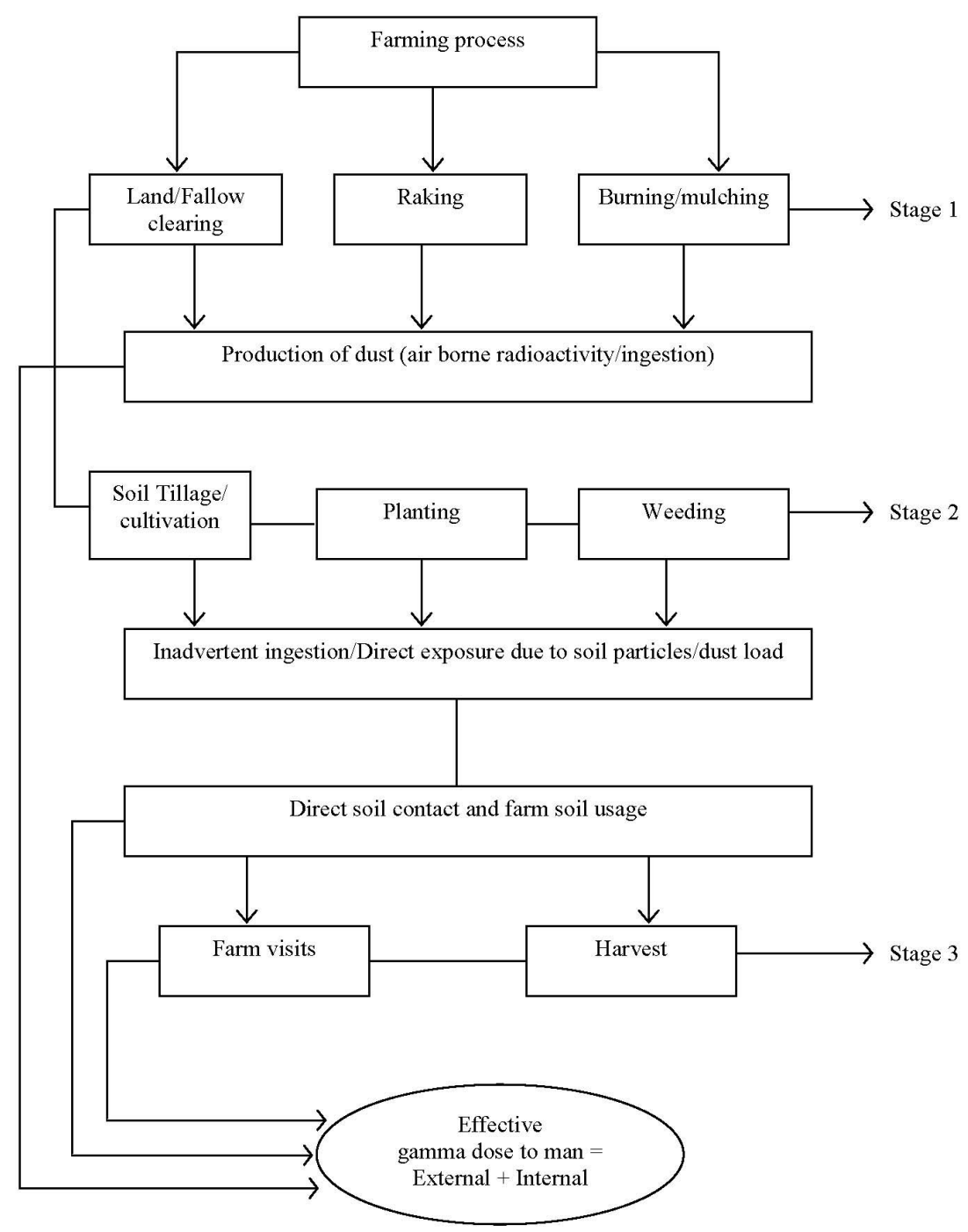

Figure 1 - Flow diagram of exposure scenario and exposure pathways due to farming.

Organigramme du scénario d'exposition et des cheminements de l'exposition, dus à l'agriculture.

Studies concerning occupational exposure to dust and ingestion of soil particles among farmers are justified because of the insufficient research in this field; such study should approach the whole of a farmer's work from the point of view of the work site. Unlike in industry, exposure to dust at this work site takes place in 
changeable conditions with respect to concentration and composition of dust, work post and daily working time; also during the prolonged work cycle which, in the case of plant production may even take a whole year (Molocznik and Zagorski, 1998). Apart from high air temperature, vibration and noise, agricultural dust is considered by farmers themselves as an unfavourable factor which most often accompanies their occupation. Epidemiologic studies carried out among farmers indicate a clear relationship between the occurrence of dust-related pathologic symptoms, concentration of dust and its pathogenic components and the period of occupational exposure to agricultural dust; however, the lack of data concerning the exposure has not created a means to discover the relationship between exposure and health effects (Tegen et al., 2004; Molocznik and Zagorski, 1998).

Previous research reports on environmental radioactivity studies in the Jos Plateau have indicated high gamma radiation dose rates in excess of world average value (Oresegun and Babalola, 1990, 1993; Farai and Jibiri, 2000). Majority of these reports attributed these high levels primarily on the influence of tin and its mining activities in the area while the influence of the geological formation of the area was also identified as a factor (Farai and Jibiri, 2000; Jibiri et al., 2007a, 2007b; Jibiri and Agomuo, 2007; Ademola, 2008). Presently, no attempt has been made to consider singularly farm soils in relation to radioactivity levels, the effects it portents to the farmers during farming activities based on the fact that the areas under investigation are known for high radiations. The study considered and assumed the work sites typical of rural agriculture for peasant farmers in Nigeria: private family farm. The present study is therefore imperative as it will provide information on the radiation exposure of local farmers or the population in these areas. The evaluation of exposure creates a possibility to evaluate the health risk among the farming population, which to date has not been covered by legal regulations concerning health protection of the working population or even attempted from the weight of work done in environmental radioactivity. It will in the overall interest add to the radiometric data on environmental radioactivity needed in the country as the result presented in this paper constitute the first attempt to recognize the internal exposure due to dust inhalation and soil ingestion arising from farming in soils in high background radiation areas. The specific objectives of this study are as follows:

(1) determine the activity concentrations of natural radioactive elements in the farm soils from agricultural farmlands in three major old tin mining sites; Bitsichi, Bukuru and Ropp in Jos-Plateau Nigeria,

(2) estimate the external gamma exposure dose rates due to resident time in the farms and finally,

(3) estimate the internal gamma doses resulting from-dust inhalation and inadvertent ingestion of soil particles during farming. 


\section{Materials and methods}

\subsection{Soil sample collection}

At each farmland in the three areas under investigation, soil samples were collected to a depth of $150 \mathrm{~mm}$ from 3 to 5 spots with an average area of $2 \mathrm{~m}^{2}$; each spots being separated from each other by at least $10 \mathrm{~m}$. All the samples from the spots were mixed thoroughly as a composite sample that is representative for the farm. They were transferred into a polythene bag and taken to the laboratory for processing. A total of 55 farmlands across the three localities were covered in this study comprising of 37 from Bitsichi, 14 from both Bukuru and Ropp.

At the laboratory, extraneous materials like plant materials, roots, pebbles were deliberately not removed. These extraneous materials are part of sources of radiation exposure in the farm. The deliberate attempt will ensure retaining all the contributing exposure elements in the environment. The soil samples along with the extraneous materials were dried at $110^{\circ} \mathrm{C}$ in a temperature controlled oven until there was no detectable change in the mass of the sample. The dried samples were thoroughly crushed, grounded and pulverized to powder. The powder was passed through a 2-mm mesh sieve. Due to the limited space of the detector shield only $200 \mathrm{~g}$ of the soil samples (dry-weight) were used for analysis since, this is the quantity it could conveniently take. The samples after weighing were transferred to radon-impermeable cylindrical plastic containers of uniform size $(60 \mathrm{~mm}$ height by $65 \mathrm{~mm}$ diameter) and were sealed for a period of about 30 days. This was done in order to allow for Radon and its short-lived progenies to reach secular radioactive equilibrium prior to gamma spectroscopy. The standard reference soil sample used for activity determination of the radionuclides considered in this study was also transferred to a container of the same material and dimensions as were used for the soil samples. This is to ensure that the geometry configuration remained the same. The standard reference soil sample used was prepared from Rocketdyne Laboratories California; USA which is traceable to a mixed standard gamma source (Ref. No. 48722-356) by Analytic Inc. Atlanta, Georgia.

\subsection{Method of measurement}

A lead-shielded $76 \mathrm{~mm} \times 76 \mathrm{~mm} \mathrm{NaI}(\mathrm{TI})$ detector crystal (Model No. 802 series, Canberra Inc.) coupled to a Canberra Series 10 plus Multichannel Analyzer (MCA) (Model No. 1104) through a preamplifier was used for the radioactivity measurements carried out in this study. It has a resolution (FWHM) of about $8 \%$ at energy of $0.662 \mathrm{MeV}\left({ }^{137} \mathrm{Cs}\right)$ which is considered adequate to distinguish the gamma ray energies of interest in the present study. The choice of gamma-ray 
peaks of the radionuclides to be used for measurements was made considering the fact that the $\mathrm{NaI}(\mathrm{Tl})$ detector used in this study had a modest energy resolution. This was to ensure that the photons emitted by the radionuclides would only be sufficiently discriminated if their emission probability and their energy were high enough, and the surrounding background continuum low enough. Therefore, the activity concentration of ${ }^{214} \mathrm{Bi}$ (determined from its $1.760 \mathrm{MeV} \gamma$-ray peak) was chosen to provide an estimate of ${ }^{226} \mathrm{Ra}\left({ }^{238} \mathrm{U}\right)$ in the samples, while that of the daughter radionuclide ${ }^{208} \mathrm{Tl}$ (determined from its $2.615 \mathrm{MeV} \gamma$-ray peak) was chosen as an indicator of ${ }^{232} \mathrm{Th}$. Potassium-40 was determined by measuring the $1.460 \mathrm{MeV} \gamma$-rays emitted during its decay. The detailed calibration of the detector can be found in our earlier publications (Obed et al., 2005; Jibiri and Bankole, 2006; Jibiri and Agomuo, 2007).

The soil samples were placed symmetrically on top of the detector and measured for a period of 10 hours. The net area under the corresponding peaks in the energy spectrum was computed by subtracting counts due to Compton scattering of higher peaks and other background sources from the total area of the peaks. From the net area, the activity concentrations in the samples were obtained using the equation (Jibiri and Bankole, 2006; Jibiri et al., 2007a, 2007b):

$$
C\left(\mathrm{~Bq} \mathrm{~kg}^{-1}\right)=k C_{n}
$$

where $k=\frac{1}{\varepsilon P_{\gamma} M_{s}}, C$ is the activity concentration of the radionuclide in the sample given in $\mathrm{Bq} \mathrm{kg}^{-1}, C_{n}$ is the count rate under the corresponding peak, $\varepsilon$ is the detector efficiency at the specific $\gamma$-ray energy, $P_{\gamma}$ is the absolute transition probability of the specific $\gamma$-ray, and $M_{s}$ is the mass of the sample $(\mathrm{kg})$.

\section{Results and discussions}

\subsection{Activity concentration levels of the radionuclides}

Table I presents the range, mean and standard deviations of the measured activity concentrations of ${ }^{226} \mathrm{Ra},{ }^{232} \mathrm{Th}$ and ${ }^{40} \mathrm{~K}$ in the farm soils for the three areas under investigation. The error terms in the range of the activity concentration of the radionuclides represent the combined uncertainties due to gamma counting, efficiency determinations, etc. As could be observed from the table, the highest concentration of ${ }^{40} \mathrm{~K}$ in the study was obtained in Ropp whereas those of ${ }^{226} \mathrm{Ra}$ and ${ }^{232} \mathrm{Th}$ were only obtained in Bitsichi. The concentration of the three radionuclides as could be seen from Table I were higher than the world average in soils which are; $420 \mathrm{~Bq} \mathrm{~kg}^{-1}, 32 \mathrm{~Bq} \mathrm{~kg}^{-1}$ and $45 \mathrm{~Bq} \mathrm{~kg}^{-1}$ for ${ }^{40} \mathrm{~K},{ }^{226} \mathrm{Ra}$ and ${ }^{232} \mathrm{Th}$, respectively (UNSCEAR, 2000). This may be attributed to the influence of different farm 
ASSESSMENT OF EXTERNAL AND INTERNAL DOSES

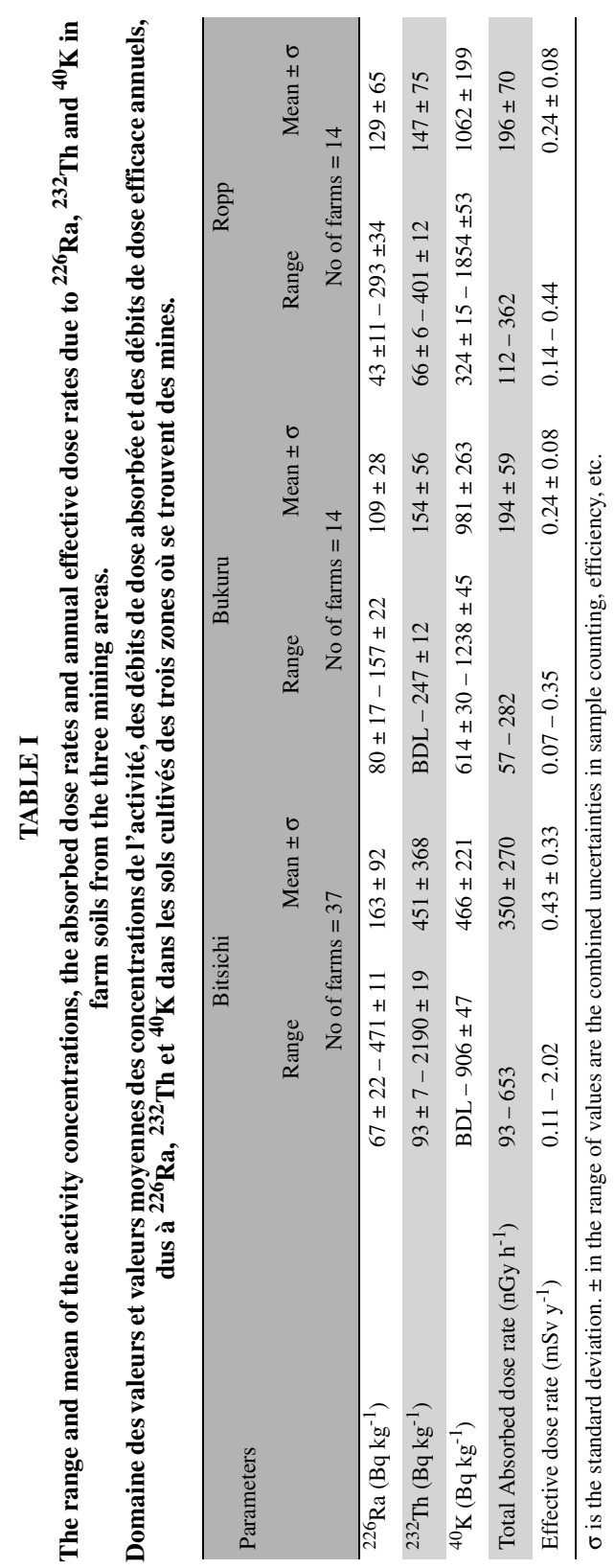


practices employed in improving the soil fertility due to poor yield of farm products from these areas and the extraneous concentration values of the radionuclides obtained in some of the farms. According to Jibiri et al. (2007a, 2007b), Jibiri and Agomuo (2007), Alexander and Kidd (2000) and Pasquini and Alexander (2005), heavy applications of different brands of chemical fertilizers and refuse ash were used by local farmers to improve the soil fertility and reclamation initiatives. Mittra et al. (2003) reports that one of the possible ways of enhancing productivity of acidic soil is the use of fly ash in appropriate combination with organic matter and chemical fertilizer which would act as soil amendment and source of nutrient supply system. These practices would have modified the concentrations of these radionuclides and their distribution hence altering their natural processes in the farm soils in these areas under investigation.

\subsection{Dose calculations}

\subsubsection{Absorbed dose rates}

The external absorbed dose rate, $D\left(\mathrm{nGy} \mathrm{h}^{-1}\right)$ in air at $1 \mathrm{~m}$ above the ground level for soils containing the concentrations of the radionuclides measured in the samples is calculated using the equation (UNSCEAR, 2000; Mustapha et al., 2007):

$$
D_{\text {ext }}=\sum_{R} A_{R} D C_{\text {ext }, R}
$$

where $D C_{\text {ext } R}$ is the coefficient of dose rate per unit activity concentration of radionuclide $R$ (in $\mathrm{Bq} \mathrm{kg}^{-1}$ ) and $A_{R}$ is the concentration of the radionuclide $R$ in the sample $\left(\mathrm{Bq} \mathrm{kg}^{-1}\right)$. The United Nation Scientific Committee on the Effects of Atomic Radiation (UNSCEAR, 2000) prescribes $D C_{\text {ext } R}$ coefficient of ${ }^{226} \mathrm{Ra}$ as $4.62 \times 10^{-10} \mathrm{~Gy} \mathrm{~h}^{-1} / \mathrm{Bq} \mathrm{kg}^{-1},{ }^{232} \mathrm{Th}$ as $\left.6.04 \times 10^{-10} \mathrm{~Gy} \mathrm{~h}^{-1} / \mathrm{Bq} \mathrm{kg}^{-1}\right),{ }^{40} \mathrm{~K}$ as $0.417 \times$ $10^{-10} \mathrm{~Gy} \mathrm{~h}^{-1} / \mathrm{Bq} \mathrm{kg}^{-1}$ and ${ }^{137} \mathrm{Cs}$ as $0.30 \times 10^{-10} \mathrm{~Gy} \mathrm{~h}^{-1} / \mathrm{Bq} \mathrm{kg}^{-1}$ ). Since ${ }^{137} \mathrm{Cs}$ was not detected in any of the samples, its coefficient was taken as zero. The range and mean values of external absorbed dose rates obtained are summarized in Table I for the different areas under investigation.

\subsubsection{Outdoor effective dose due to $\gamma$-rays emitted by radionuclides contained in the environment}

The absorbed $\gamma$-dose rates in air are usually related to human absorbed $\gamma$-dose in order to asses radiological implications. The external effective dose $D_{\text {ext }}\left(\mathrm{Sv} \mathrm{y}^{-1}\right)$ received by an individual due to the distribution of the radionuclides in the farms during farming or during any of the external exposure scenario (Fig. 1) was estimated. In assessing the outdoor effective dose equivalent to members of the 
population, two important factors were considered. The first is a factor that converts the absorbed dose rates $\left(\mathrm{Gy} \mathrm{h}^{-1}\right)$ in air to human outdoor effective dose rates $\left(\mathrm{Sv}^{-1}\right)$ while the second factor gives the proportions of the total time for which the typical individual is exposed to outdoor or indoor radiation. The United Nation Scientific Committee on the effect of Atomic Radiation (UNSCEAR, 2000) has recommended $0.7 \mathrm{~Sv} \mathrm{~Gy}^{-1}$ as the value of the first factor and 0.2 and 0.8 as for outdoor and indoor occupancy factors, respectively. This second factor implies that the average individual spends only 4.8 hours (about 5 hours per day) outdoors. In this work, only outdoor exposure from $\gamma$-rays sources due to the concentrations of the primordial radionuclides in the soil were considered. Since we are considering exposure scenario to farmers resulting from radionuclide concentrations in farm soil, the outdoor occupancy factor was modified to reflect that for a typical peasant farmers in Nigeria. An average occupancy factor of $10 \mathrm{~h} \mathrm{~d}^{-1}$ was adopted for a typical peasant farmer in Nigeria. The effective dose rate resulting from the absorbed dose rate values was calculated using the following relation:

$$
E_{\text {ext }}=T f Q D_{\text {ext }}
$$

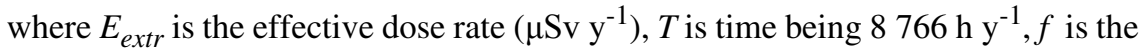
outdoor occupancy factor that corrects for the average time spent outdoors $(0.4)$ $(\sim 10 \mathrm{~h}), Q$ is the quotient of the effective dose rate and absorbed dose rate in air $\left(0.7 \mathrm{~Sv} \mathrm{~Gy}{ }^{-1}\right)$, and $D_{\text {ext }}$ is the absorbed dose rate in air $\left(\mathrm{nGy} \mathrm{h}^{-1}\right)$. The values obtained across the farms are summarized in Table I for Bitschi, Ropp and Bukuru. The annual effective dose due to external exposure as can be seen from Table I varied from $0.07 \mathrm{mSv}$ to $2.02 \mathrm{mSv}$ across the areas. The average values for each of the area were all greater than annual value of $0.07 \mathrm{mSv} \mathrm{y}^{-1}$ for outdoor exposures (UNSCEAR, 2000).

\subsubsection{Internal dose due to the inhalation of air contaminated with soil dust}

Due to the specific character of production processes in agriculture, workers employed in this sector of the economy are exposed to dust in changeable conditions, associated with a variety of work activities, variability of concentrations and composition of dust, work site and the daily time of exposure, as well as the duration of working cycle, which in plant production covers the whole year. This is typical of peasant farming system in Nigeria which is largely characterized by time consuming manual occupations associated with the cultivation of crop and everyday care of breeding stock, which creates a peculiar type of background in the annual work of a private farmer. Confirmed pathogenic properties, noted among farmers, were based on the studies of the total dust load (Molocznik and Zagorski, 1998). Hence, the effective internal dose due to 


\section{TABLE II}

Effective doses per unit intake of ${ }^{226}$ Ra and ${ }^{232}$ Th including contributions from their short-lived products by ingestion and inhalation pathways for adults ( $>17$ years) (Adapted from Mustapha et al., 2007)

Doses efficaces par prise unitaire de ${ }^{226} \mathrm{Ra}$ et ${ }^{232} \mathrm{Th}$ - incluant les contributions de leurs descendants à vie courte - par ingestion et par inhalation, pour des adultes (>17 ans) - Adapté de Mustapha et al. (2007).

\begin{tabular}{ccc}
\hline Radionuclide & $\begin{array}{c}\text { Inhalation }\left(\mathrm{nSv} \mathrm{Bq}^{-1}\right) \\
(\text { absorption type })\end{array}$ & Ingestion $\left(\mathrm{nSv} \mathrm{Bq}^{-1}\right)$ \\
\hline${ }^{226} \mathrm{Ra}$ & $\begin{array}{c}5600 \\
(\text { medium })\end{array}$ \\
${ }^{232} \mathrm{Th}$ & $\begin{array}{c}12000 \\
(\text { small })\end{array}$ \\
\hline
\end{tabular}

inhalation $D_{i n h}\left(\mathrm{~Sv} \mathrm{y}^{-1}\right)$ is calculated using the equation:

$$
D_{i n h}=\sum_{R} A_{R} D C_{i n h, R} C_{d s} I_{i n h} T
$$

where $D C_{i n h, R}$ is the effective dose per unit intake coefficient for radionuclide $R$ $\left(\mathrm{Sv} \mathrm{Bq}{ }^{-1}\right)$ by inhalation, $C_{d s}$ is the mass loading $\left(\mathrm{g} \mathrm{m}^{-3}\right), I_{i n h}$ is the inhalation rate, and $T$ and $A_{R}$ have been defined in equations (2) and (3). The mass loading parameter is the concentration of soil particles in the air. The estimated mass loading for construction activities is about $6.0 \times 10^{-4} \mathrm{~g} \mathrm{~m}^{-3}$; for exposure to construction traffic on unpaved roads it is $4.0 \times 10^{-4} \mathrm{~g} \mathrm{~m}^{-3}$; and for agriculture-generated dust for private farming it is about $3.0 \times 10^{-4} \mathrm{~g} \mathrm{~m}^{-3}$ (Yu et al., 1993) while for mechanized tractor based farming it about $3.57 \times 10^{-3} \mathrm{~g} \mathrm{~m}^{-3}$ (Molocznik and Zagorski, 1998). Suitable dust loading rates for scenarios considered in this study were determined according to the rational presented by previous reports (Yu et al., 1993; Oatway and Mobbs, 2003; Mustapha et al., 2007). We have therefore adopted $3.0 \times 10^{-4} \mathrm{~g} \mathrm{~m}^{-3}$ as the dust load and EPA (1997) recommended $1.5 \mathrm{~m}^{3} \mathrm{~h}^{-1}$ inhalation rate for outdoor workers in moderate activities such as farming operations. Using the inhalation $D C_{i n h, R}$ values for each of the radionuclide in Table II, the radionuclide concentrations, the dust load and inhalation rates, $D C_{i n h}$ of each radionuclide was estimated. The results are presented in Table III. The total annual average value estimated for Bitsichi is $9.9 \mu \mathrm{Sv}, 3.9 \mu \mathrm{Sv}$ for Bukuru and 3.9 $\mu \mathrm{Sv}$ for Ropp.

\subsubsection{Internal dose due to inadvertent ingestion of radionuclides}

Estimates of risk attributable to soil contamination are often dependent upon assumed soil ingestion rates. Sources of ingestion rate estimates include calculation from assumptions regarding soil loading on hands, frequency of handto-mouth contact, and efficiency of transfer (Kissel et al., 1998). During farming there is the chance of inadvertent ingestion which in this work is assumed to occur 
TABLE III

Calculated average annual inhalation and ingestion effective dose rates due to ${ }^{226} \mathbf{R a}$ and ${ }^{232}$ Th to the population in the areas.

Valeurs calculées des débits annuels moyens de dose efficace, par inhalation et ingestion ${ }^{d e}{ }^{226} \mathrm{Rn}$ et ${ }^{232} \mathrm{Th}$, pour les populations des trois zones.

\begin{tabular}{ccccccc}
\hline \multirow{2}{*}{ Radionuclide } & \multicolumn{2}{c}{ Bitsichi $\left(\mathrm{mSv} \mathrm{y}^{-1}\right)$} & \multicolumn{2}{c}{ Bukuru $\left(\mathrm{mSv} \mathrm{y}^{-1}\right)$} & \multicolumn{2}{c}{ Ropp $\left(\mathrm{mSv} \mathrm{y}^{-1}\right)$} \\
& \multirow{2}{*}{ Inhalation } & Ingestion & Inhalation & Ingestion & Inhalation & Ingestion \\
\hline${ }^{226} \mathrm{Ra}$ & $1.4 \times 10^{-3}$ & $5.7 \times 10^{-3}$ & $0.96 \times 10^{-3}$ & $3.8 \times 10^{-3}$ & $1.1 \times 10^{-3}$ & $4.5 \times 10^{-3}$ \\
${ }^{232} \mathrm{Th}$ & $8.5 \times 10^{-3}$ & $1.2 \times 10^{-3}$ & $2.9 \times 10^{-3}$ & $0.4 \times 10^{-3}$ & $2.8 \times 10^{-3}$ & $0.4 \times 10^{-3}$ \\
\hline
\end{tabular}

through hand to mouth transfer of soil or dust present on the skin or clothing. The effective dose $D_{\text {ing }}\left(\mathrm{Sv} \mathrm{y}^{-1}\right)$ due to inadvertent ingestion of radionuclides through soil ingestion either during tillage, weeding or by other means in the farms is calculated using the equation:

$$
D_{\text {ing }}=\sum_{R} A_{R} D C_{\text {ing }, R} I_{\text {ing }} T
$$

where $I_{\text {ing }}$ is the ingestion rate $\left(\mathrm{g} \mathrm{h}^{-1}\right), D C_{\text {ing, } R}$ is the effective dose per unit intake conversion coefficient for radionuclide $R\left(\mathrm{~Sv} \mathrm{~Bq}^{-1}\right)$ by ingestion and all other terms have their meanings as described in the equations above. According to Mustapha et al. (2007), the amount of soil that is likely to be inadvently ingested by an adult in digging and extracting soils containing coltan ore is $5 \times 10^{-3} \mathrm{~g} \mathrm{~h}^{-1}$. For agriculture, a conservative adult soil ingestion rate of $200 \mathrm{mg} \mathrm{d}^{-1}$ is recommended by EPA (1997) for agricultural operations in which there exist enhanced soil ingestion scenarios. Using $D C_{i n g, R}$ values for ingestion in Table II and the recommended ingestion rates, $D C_{i n h}$ were estimated. The results are presented in Table III. The calculated total average annual effective dose rates that could result from inadvertent ingestion of radionuclides during farming to the population is therefore, $6.9 \mu \mathrm{Sv}$ for Bitsichi, $4.2 \mu \mathrm{Sv}$ for Bukkuru and $4.9 \mu \mathrm{Sv}$ for Ropp.

These calculations are however, done while appreciating the major limitation that, the parameters used for calculations apart from standard conversion coefficients are only conservative estimates which would need to be validated by measurements. The work presented in this study constitutes the first attempt to recognize the exposure to dust and inadvertent ingestion of soil at workplaces in agriculture during an annual cycle. A more comprehensive recognition of exposure requires further studies with the consideration of the respirable fraction and various conditions of exposures. The evaluation of these exposure pathways nevertheless of low values obtained in this work is important from radiation protection point of view. It will create the possibility and the need to evaluate the health risk among 
the farming population and agricultural working environments in the country or elsewhere which to date is not covered by regulations concerning health protection. As occupational exposure to dust and ingestion may be hazardous in agricultural environment and that the character of exposure is changeable, it may indicate the necessity of applying special strategies in work environments.

\section{Conclusion}

The activity concentrations of natural radionuclides $\left({ }^{226} \mathrm{Ra},{ }^{232} \mathrm{Th}\right.$ and $\left.{ }^{40} \mathrm{~K}\right)$ in farm soil samples from three major old tin mining areas in Jos-Plateau Nigeria have been determined using gamma-ray spectroscopy. Using the activity concentrations of the radionuclides, the external absorbed dose rates, the corresponding annual outdoor effective dose rates were calculated. The value obtained ranged between $0.07 \mathrm{mSv} \mathrm{y}^{-1}$ and $2.02 \mathrm{mSv} \mathrm{y}^{-1}$ across the three areas. Considering the possible exposure pathways and scenarios from farming activities, the total average annual internal effective dose rates estimated that could result from dust inhalation and ingestion of soil particles during farming practices in these areas were $16.9 \mu \mathrm{Sv}$, 8.1 $\mu \mathrm{Sv}$ and $8.8 \mu \mathrm{Sv}$ for Bitsichi, Bukuru and Ropp, respectively. The evaluation of these exposure pathways nevertheless of low values obtained cannot be neglected from risk and radiation protection point of view. However, this will create the possibility to evaluate the health risk among the farming population and agricultural working environments. The occupational exposures to dust and soil ingestion is seen to be hazardous in agricultural environments where the soil is highly contaminated by radioactive elements of either natural or anthropogenic sources and may therefore indicate the necessity of applying special strategies in agricultural work environments and technical prophylactic approaches.

Acknowledgements. The authors wish to thank the International Foundation for Science (IFS), Stockholm, Sweden for the research grants (Ref. Nos. E-3585-1 and E-3585-2) awarded to one of the authors; Dr Nnamdi.N Jibiri under its food Science Programme. The technical supports from these grants made this present study possible. We are also grateful to the Department of Physics, University of Ibadan, Nigeria for the access to the gamma-ray spectroscopic assembly.

\section{REFERENCES}

Ademola J.A. (2008) Exposure to high background radiation level in the tin mining area of Jos Plateau Nigeria, J. Rad. Prot. 28, 93-99.

Alexander M.J., Kidd A.D. (2000) Farmer's capability and institutional incapacity in Reclaiming disturbed land on the Jos Plateau, Nigeria, J. Environm. Manag. 59, 141-155.

EPA (1997) Environmental Protection Agency, Exposure factors Hand Book. United States Environmental Protection Agency, National Centre for Environmental Assessment Office of Research and Development, Washington DC. 
Farai I.P., Jibiri N.N. (2000) Baseline studies of terrestrial outdoor gamma dose rate levels in Nigeria, Radiat. Prot. Dosim. 88, 247-254.

Jibiri N.N., Agomuo J.C. (2007) Trace elements and radioactivity measurements in some terrestrial food crops in Jos-Plateau, Northcentral, Nigeria, Radioprotection 42, 29-42.

Jibiri N.N., Bankole O.S. (2006) Soil radioactivity and radiation absorbed dose rates at roadsides in high-traffic density area in Ibadan Metropolis, southwestern, Nigeria, Radiat. Prot. Dosim. 118, 453-458.

Jibiri N.N., Farai I.P., Alausa S.K. (2007a) Estimation of annual effective dose due to natural radioactive elements in ingestions of foodstuffs in tin mining area of Jos-Plateau, Nigeria. $J$. Environm. Radioact. 94, 31- 40.

Jibiri N.N., Farai I.P., Alausa S.K. (2007b) Activity concentrations of ${ }^{226} \mathrm{Ra},{ }^{228} \mathrm{Th}$, and ${ }^{40} \mathrm{~K}$, in different food crops from a high background radiation area in Bitsichi, Jos Plateau, Nigeria, Radiat. Environm. Biophys. 46, 53-59.

Kissel J.C., Shirai J.H., Richter Y., Fenske R.A. (1998) Empirical investigation of hand-to-mouth transfer of soil, Bull. Environm. Contamin. Toxicol. 60, 379-386.

Mittra B.N., Karmakar S., Swain D.K., Ghosh B.C. (2003) Fly ash- a potential source of soil amendment and a component of integrated plant nutrient supply system. International ash utilization symposium, Center for Applied Energy Research, University of Kentucky. Paper No. 28 (http://www.flyash.info).

Molocznik A., Zagorski J. (1998) Exposure to dust among agricultural workers, Ann. Agric. Environ. Med. 5, 127-130.

Mustapha A.O., Mbuzukongira P., Mangala M.J. (2007) Occupational radiation exposures of artisans mining columbite-tantalite in the eastern Democratic Republic of Congo, J. Rad. Prot. 27, $187-195$

Oatway W.B., Mobbs S.F. (2003) Methodology for estimating the doses to members of the public from the future use of land previously contaminated with radioactivity NRPB-W36 (Chilton: NRPB).

Obed R.I., Farai I.P., Jibiri N.N. (2005) Population dose distribution due to soil radioactivity concentration levels in 18 cities across Nigeria, J. Rad. Prot. 25, 305-312.

Oresegun M.O., Babalola I.A. (1990) Occupational radiation exposure associated with milling of Th-U rich Sn in Nigeria, Health Phys. 58, 213-215.

Oresegun M.O., Babalola I.A. (1993) The environmental gamma radiation level of Jos, Nigeria, Niger. J. Sci. 27, 263-268.

Pasquini M.W., Alexander M.J. (2005) Soil fertility management strategies on the Jos Plateau: the need for integrating empirical and scientific knowledge in agricultural development, Geograph. J. 171, 112-124.

Tegen I., Werner M., Harrison S.P., Kohfeld K.E. (2004) Relative importance of climate and land use in determining present and future global soil dust emission, Geophys. Res. Lett. 31, L05105, DOI: $10.1029 /$ GLO.1912.

UNSCEAR (2000) United Nations Scientific Committee on the effects of Atomic Radiation, Report to the General Assembly, New York: United Nations.

Yu C., Loureiro C., Cheng J.J., Jones L.G., Wang Y.Y., Chia Y.P., Faillace E. (1993) Data collection handbook to support modeling impacts of radioactive material in soil. Environmental Assessment and Information Sciences Division Argonne National Laboratory, Argonne, Illinois. 